\title{
A Political Economy of Trans-Border Migration Crises and Human Trafficking in Africa
}

\begin{abstract}
Encouraged by porous border boundaries in Africa, trafficking in persons and objects is a demand-driven global venture that has market potential for: commercial sex, cheap labour, terrorism, and drug-related crimes. Most African States, especially Nigeria, have been reputed as hardliners in encouraging these illicit trends. Chief among the motivating factors include: domestic insecurity, political instability, economic recession, and institutional failure, etc. Amongst other instigating factors however, this paper takes a cursory look at the relationship between the twin crime of trans-border migration crises and human trafficking in Nigeria, and the attendant political economic implications on the Nigerian polity. Data relied on are largely gotten from secondary sources. The paper employs the neoclassical political economic theory of migration. Findings from conceptual and theoretical reviews of literatures show that the incentive for human trafficking and migration-related offences is not only profit driven but also a fall-out from institutional failure. The paper recommends a taut border security, which can disallow border-related crimes like drug and human trafficking. The paper also sues for people-oriented leadership that will eschew illicit crimes such as the above.
\end{abstract}

Key words: migration, human trafficking, drug trafficking, terrorism, commercial sex, neoclassical political economy

\subsection{General Background}

\section{Introduction}

$\mathbf{H}$ uman migration has long been considered an important element of population dynamics, which can have significant consequences on both areas of origin and destination. Specifically, migration trends in Africa portray some changing demographic characteristics and challenges. Its main drivers are now diverse and in response to not only domestic challenges within most African states, but also a reflection of wider global impulses. The open spaces created by trans-border migration pose new challenges for development, while remittances and return migration have potentials for enhanced development of sending areas (Yaro, 2008).

Thus, even though it is increasingly imperative to establish the connectivity between the motivations for migration and human trafficking, the concomitant outcomes for national development abound. For one: the exploitation and trafficking of men, women, and children, is a humanitarian problem of global scale. A recent study estimates that at least 12 million people worldwide are trapped in conditions of forced labour. Around a fifth of these are being exploited as a result of human trafficking (ILO, 2005). 
In a spatial sense invariably, employment opportunities and developmental changes have been concentrated in a few areas, especially the cities; the rural areas, which dominate both in terms of population numbers and areal extent, have either undergone little growth or have felt the backwash effects of development elsewhere (Hirschman, 1958; Myrdal, 1957). Hence, encouraged by the need to enhance their livelihood and for better living conditions, migrants from this perspective often drift from rural to urban areas in response to developmental setbacks.

This paper therefore takes a cursory look at the twin crises of trans-border migration and human trafficking, specifically in Nigeria and Africa in general. The essence is to proliferate the extant literatures in this area. It is also a significant attempt to question the close link between trafficking and labour migration, and how they differ from that of many recent media and policy reports. This is because most reports, as Mahmoud and Christoph (2010) argued, point to: legislation and law enforcement, poor border controls, bribery and corruption, or insufficient education, as drivers of human trafficking. These factors certainly exacerbate the trafficking problem, but may not explain it at its core.

The daunting economic and political instability may as well be a push for migration trend. This is because opportunities for job mobility, business ventures, personal leisure/ relaxation, and greener pastures, may be opened outside the frontiers of a nation's domestic boundary. Insecurity and political crises could also pose some sort of challenges, and hence the desire to migrate. Other reasons span from trade in illicit businesses like drugs, human parts/organs, to smuggling of contraband, goods, and services.

\section{Research Questions}

Arising from the above background, this study raises the following research questions:

i. What are the causes of trans-border migration and human trafficking in Nigeria?

ii. What is the political economy of trans-border migration and human trafficking in Nigeria?

iii. What are the implications of migration and human trafficking on the Nigerian state?

\subsection{Conceptual/Theoretical Clarifications}

\section{Migration}

According to Oderth (2002), migration has shaped the nature of both receiving and places of origin more than any other phenomenon in human geography. Albeit, the concept has been given various intellectual attentions. Like most terms in the Social Science it is nonetheless a deliberate response to societal ills, and an attempt to structurally adapt according to human needs and necessities.

The Encyclopedia of the Social Sciences defines migration as "the movement of people over considerable distances and on a large scale with the intention of abandoning 
former homes." It is also defined as a permanent or semi-permanent change of residence. No restriction is placed upon the distance of the move and or upon the voluntary or involuntary nature of the act, and no distinction is made between external and internal migration. Hence, the ability to move from one country to the other (which may even be a short distance such as cross-border movement between Nigeria and Niger Republic or Nigeria and Benin Republic) is termed migration (Todaro, 1969). Migration is undoubtedly inspired by economic opportunity or criminal intentions, exemplified in trafficking and smuggling of: persons, goods, and services. Including: drug trafficking and smuggling, prostitution rings and criminal behavior, which dents the image of the country.

\section{Forms of Migration}

It is pertinent to stress, that although the paper pointed out that different forms of migration ranging from: internal migration caused by economic hardships, to internally displaced persons caused by wars and famine representing different forms of phenomenon. The paper identified illegal migration which produces Refugees and Asylum Seekers in Europe and North America as the common forms of migration into in Europe by Nigerians and other Africans.

\section{Challenges Faced by Migrants}

Several challenges confront migrants during and after crossing the Sahara desert, and the Mediterranean Sea into Europe. Common ones are death, slavery, sickness, and their change of status to illegal migrants and refugees.

\section{Trafficking/Human Trafficking}

The UN Convention Against Transnational Organized Crime (2000) considered Trafficking to mean: the recruitment, transportation, transfer, harbouring or receipt, of persons. Whether by means of the threat or use of force, or other forms of coercion such as: abduction,- fraud, deception, abuse of power or of a position of vulnerability, the giving or receiving of payments or benefits to achieve the consent of a person having control over another person for the purpose of exploitation.

The convention (UN, 2010) went further to state that exploitation shall include, at a minimum, the exploitation of the prostitution of others or other forms of sexual exploitation, forced labour or services, slavery or practices similar to slavery, servitude or the removal of human vital organs. The consent of a victim of trafficking in persons, to the intended exploitation, shall be irrelevant where any of the fore-mentioned means have been used. Again, the: recruitment, transfer, harbouring or receipt of a child, for the purpose of exploitation, shall be considered 'trafficking in persons' even if it does not involve any of the above listed means. "Child" shall mean any person less than eighteen years of age (Art. 3). 
The above understanding aptly conceives the concept of Trafficking from a holistic point of view as trafficking in persons is categorized as organized criminal acts, These acts transcend the conscription of persons for social crimes, but also for the marketing of the body parts of same, for the sake of profiteering. Meanwhile, most developing countries like Nigeria often present themselves as a source, transit point or recipient of trafficked persons, for domestic, social, or industrial exploitation. This is of course a reflection of state crises, and features of fragility ranging from: border porosity, economic hardship, and terrorism, to a plethora of other anti-social congruence.

\section{Neoclassical Theory of Migration}

Neoclassical theory of migration proposes wage differentials as the most important determinant of migration (Kurekova, 2011). At present, the dominant theory in explaining the causes of migration is the neoclassical theory, with its underlying assumption that migration is stimulated primarily by rational economic considerations of relative benefits and costs, These are mostly financial, but also psychological (Todaro, Smith, 2006). The theory has been subjected to criticism on conceptual (Arango, 2000) as well as on empirical grounds (Massey et al., 1998). However, owing to its analytical rigor and its ability to propose a set of testable hypotheses, and useful tools for analyzing not only the causes but also the effects of migration, it occupies a prominent position in current academic and policy-related research. The propositions of the neoclassical theory of migration were also used (almost exclusively) in the research, which preceded the 2004 Eastern enlargement of the EU (Kurekova, 2011).

The neoclassical theory understands migration to be driven by differences in returns to labor across markets. The most basic model originally developed to explain migration in the process of economic development, in the works of: Hicks (1932), Lewis (1954) and Harris and Todaro (1970). Their work highlights that migration results from actual wage differentials across markets, or countries, that emerge from heterogeneous degrees of labor market tightness. According to this theory, migration is driven by geographic differences in labor supply and demand and the resulting differentials in wages between labor-rich versus capital-rich countries. The central argument of the neoclassical approach thus concentrates on wages. Under the assumption of full employment, it predicts a linear relationship between wage differentials and migration flows (Bauer, Zimmermann, 1999; Massey et al., 1993; Borjas, 2008).

Essentially, the impetus for migration and trafficking in: persons, illicit drugs, and smuggling of goods and services; are fall-out from poor wages and the obvious need to drift from low income economic environment, to high wage labour environments. However, the drive for more income may not always present itself as the only motivation for migration. Political insecurity, ecological factors, cultural differentiation, and xenocentricism, amongst others, are unarguably causative factors for migration trend. In Nigeria, they no doubt constitute burgeoning justifications for constant exodus to Western Europe, Asia, and Northern America. Given this, the theoretical justification for this paper is premised on the neoclassical theory of Migration. 


\subsection{Methodology}

This research is a library research. It relies on data and information from secondary sources, which include: textbooks, journal articles, newspaper collections, and gazettes. Data are analyzed in form of content analysis.

\subsection{Political Economy of Trans-Border Migration Crises and Human Trafficking in Africa}

Africa has been presented as a dominant abode of potential human traffickers and migrants to not just Europe but the world at large. Demographic shifts in Africa in the recent past, as Gursch-Adam and Benkova (2016) put it, can be linked to: fast-paced globalisation, violence, armed conflict, and crises. In recent years these factors have had an increased impact on changes in population density, and can also be linked to changes in: birth and death rates, economic decline, and migration. This is because the twincrime is a demand-driven global business with a huge market for cheap labour and commercial sex, confronting often insufficient or unexercised policy frameworks or trained personnel to prevent it. The situation of the migrants the continent of Africa churns out yearly, constitutes a burgeoning concern to the globe. For instance, as Europe struggles to manage its largest migrant crisis in more than half a century, attention has focused largely upon the refugee flows from: Syria, Iraq, Yemen, South Sudan, and Afghanistan, where years of war and instability are driving the exodus.

As IGAD (2016) argued, in 2015, an estimated 154,000 migrants entered Europe via the Central Mediterranean Route and increase of nearly $400 \%$ over the previous year, and more than 1,000\% over 2012 - most of them from the Horn of Africa. By far the largest contingent of migrants of nearly 39,000 in 2015 from the sub-region's second smallest country Eritrea. Most cases of migration from the above argument, proves that war is one of the most prevailing causes of migration in recent times.

On the other hand, human trafficking is nonetheless worse in Nigeria. The country has acquired a reputation for being one of the leading African countries in human trafficking, with cross-border and internal trafficking. Trafficking of persons in the country, according to UNESCO (2016), is the third largest crime after economic fraud and the drug trade.

The incidents have assumed a threatening dimension. The seemingly non-conducive, socio-economic, terrain of the Nigeria polity has aided it. For some, it is an attempt to redirect the human capital into effective use elsewhere, especially in the face of daunting crises of: unemployment, underemployment, inflation, societal pressure, and the challenges of self-preservation. They present a case of the utter unresponsiveness of the Nigerian state, like most African states, to ensure the social security of her populace, given poor states' response to insecurity, ethno-religious conflicts, food insecurity, heightened inflation, nepotism, mediocrity and otherwise.

A recent study by UNESCO (2006) reported that decades of military regimes in Nigeria have led to the institutionalized violation of human rights, and severe political, social, and economic crises. This negatively impacts the development of community participation, especially of women and children, despite international institutions designed 


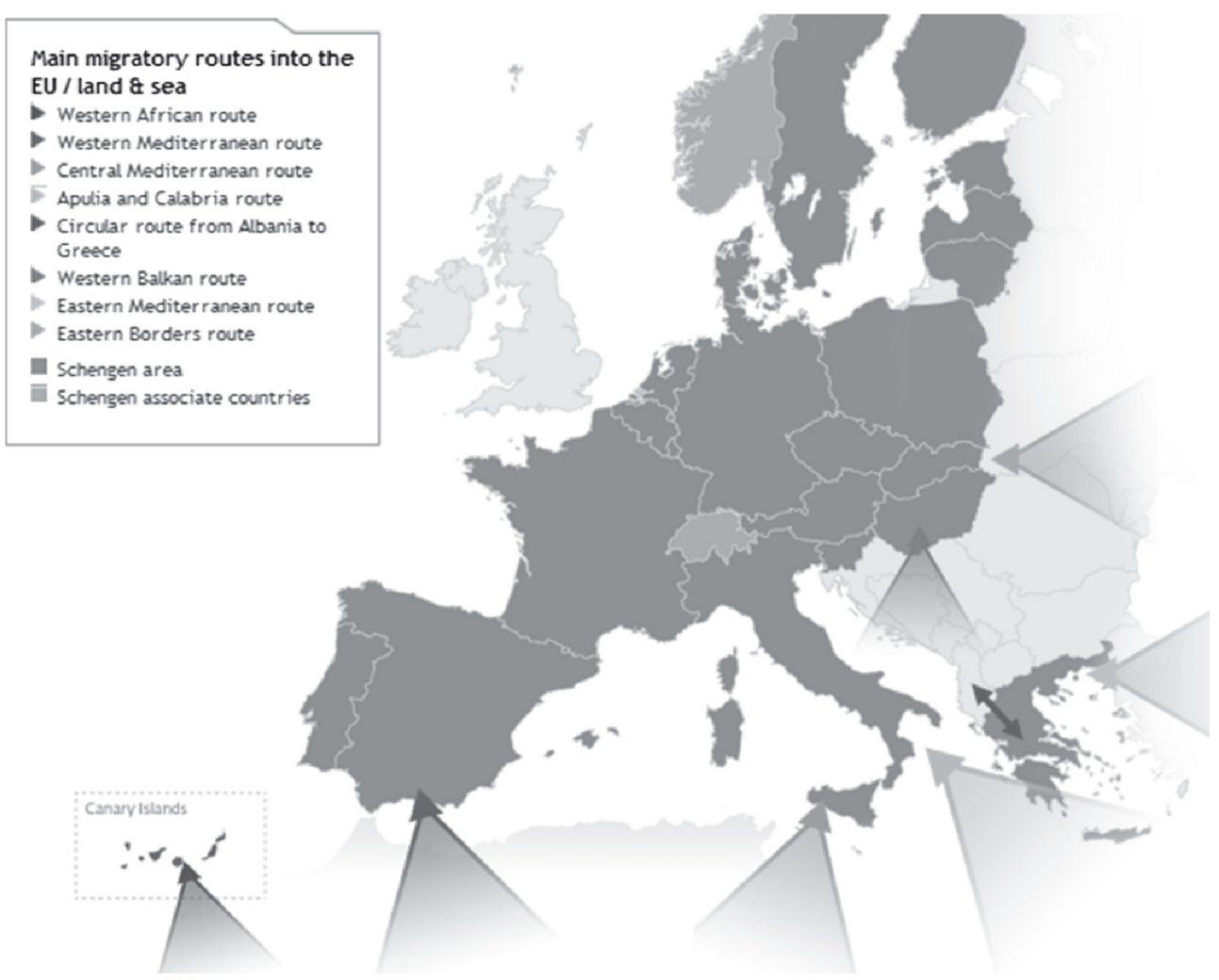

Figure 1. Migration Routes via Europe

Source: Frontex, 2016.

to advance their causes. In addition, the oil boom in the 1970s created opportunities for migration, both inside and outside of the country. This created avenues of exploitation, international trafficking in women and children, forced labor, and prostitution.

The study went further to conclude Nigeria as a country of origin, transit, and destination for human trafficking. There is also evidence of internal trafficking. Destinations for trafficked Nigerians include: the neighboring West African countries (Côte d'Ivoire, Mali, Benin, Equatorial Guinea, Cameroon, Gabon and Guinea), European countries (Italy, Belgium, Spain, the Netherlands, Germany and the United Kingdom), North Africa (Libya, Algeria and Morocco), and Middle Eastern countries (Saudi Arabia). Recently, South America has also become a point of destination for trafficked persons, particularly Venezuela. Primarily women and girls, but also boys, are trafficked for purposes of: sexual exploitation, forced labour, and organ harvesting. Poverty is the principle driving force behind this trade, propelling vulnerable people into the hands of traffickers. These traffickers, belong to both small-scale local enterprises, with extensive criminal networks, and to large-scale multi-commodity businesses (UNESCO, 2006). The debilitating implications of these ranges from: labour drain exemplified in human capital flight, to drug related offences, smuggling, displacement in persons, prostitution, death amongst litanies of embarrassing others. 


\section{Impact of Migrant Labour on Europe and Africa}

Gursch-Adam and Benkova (2016) argued that demographic pressures such as those caused by: the ageing labour force in Europe, increasing critical labour shortages, and deficits of skilled workers in developed countries, have resulted in the growth of mixed migration, both regular and irregular. The migration crisis presents a big challenge for Europe, and is steering discussions among the member states on the issue of demographic pressure as the result of: the ageing European society, concerns over national identity, migrant integration, questions regarding the economic impact of migration on the member states. As well as the importance of finding a common asylum policy and sufficiently managing the external borders of the EU. Europe is facing the worrying demographic trend of an ageing and shrinking population. The EU's total fertility rate is not much more than 1.5 children per woman. According to The 2015 Ageing Report of the European Commission: the population of the EU member states will reach 523 million in 2060, with the working-age population (15-64 years old) falling to just 202 million (European Commission, 2015c).

As the EU's working-age population will decrease by 17.5 million (European Commission, 2015a) in the next decade, there will be a high dependency ratio. Most probably resulting in reduced pension and welfare systems, and a scarcity of labour by 2035 (International Migration Institute and University of Oxford, 2011). Germany, for example, having the oldest population of all countries in Europe, is facing increased labour demands. jobs in the country are being created so fast that the native society is unable to fill them. In the long term, migration could significantly contribute to maintaining the sustainability of the welfare system. This would ensure the sustainable growth of the EU economy by filling niches in both the fast growing, and the declining sectors of the economy.

Thus, incoming educated migrants are assets with regard to the future European labour market (European Parliament, 2015). To a large extent, the future of economic growth in the EU will depend on whether young migrants arriving in Europe possess the skills needed to contribute to the efficiency of European labour markets, compared to the native population. More highly educated migrants could affect the labour market outcomes for native workers, as they could have an adverse effect on the wage and employment levels of existing workers and affect the labour supply. An increase in the population could also increase the demand for goods and services and thus affect aggregate demand (Aiyar et al. 2016a).

Additionally, the level of education and the labour status of the migrants in their countries of origin, is often a decisive factor when seeking further employment in the European labour market. However, even highly skilled migrants often face discrimination, as a large number of migrants with higher education qualifications experience professional downgrading after entering the European labour market; this is the result of a lack of recognition of qualifications from third countries, and the poor transferability of professional experience (European Research Area, 2013).

Less-educated low-skilled migrant workers may increase pressure on public services such as health care, housing, and education systems. This poses a risk of depression in public wages, and increased unemployment (Ellyatt, 2015). Low-skilled migrants are 
willing to work for lower wages than native workers and thus this puts downward pressure on wages, temporarily lowering the wages of incumbents and reducing the capitallabour ratio. Such migrants also create a less favourable net fiscal position, because as households they contribute less in taxes and social security (Dadush, 2014).

\subsection{Panacea to Illegal Migration}

Given the above discourse on the twin-crime of migration and human trafficking in Africa, the research makes the following recommendations:

\section{a. Industrialization of Africa}

Part of the reasons given by migrants from Africa, is that they have gone to seek for greener pastures. Therefore, their reasons for migration are purely economic. Consequently, there is a need to promote the industrial development of the continent, in order to create jobs that will absorb the bulging youthful population. They take the risk to travel on foot, and other dangerous means, to leave the continent of Africa for Europe. To achieve the above it is imperative that the European Union (EU) step up its support to the continents drive towards industrialization, by supporting small and medium scale industries.

\section{b. Skill Acquisition and Human Capital Development}

The acquisition of skills by Africans has also become paramount, if the trans border migration into Europe is to be curbed. Borrowing from the nine (9) cooperative plans of the president of China Xi Jinping to Africa, where china has promised to train over 200,000 Africans to acquire skills that will assist them to be relevant in the current global village, it becomes necessary for the EU to also offer such life changing opportunities to Africans.

\section{c. Stoppage of Civil Wars and Political Instability}

Europe should stop accepting to keep stolen funds from Africa, for African dictators. This is because in countries where such funds are stolen, the resultant effects has been endless civil wars and all forms of political instability (as witnessed in DR Congo, Liberia, Zaire, etc). In ensuring there are no safe heavens for money laundering abroad, is the promotion of good governance at home. In so doing the promotion of liberal democracy should be strongly supported, along with some mutually beneficial bilateral agreements with the EU Countries.

\section{d. Strengthening of Border Administration}

While free movement is promoted amongst many African regional groupings as we find elsewhere, African governments must begin to take border community adminis- 
tration more seriously with proper and adequate records maintained. Therefore, border community administration must be properly funded and supported, to achieve peace harmony and orderliness. A disciplined and well-focused border community administration will fight all illicit crimes; like trafficking in persons, drug couriers, and other crimes, that are common at the borders. By doing so hundreds of thousands of Africans Who take this unnecessary risk, that has left hundreds of thousands dead and buried in the Sahara desert, will be avoided and lives will be saved. While these solutions will help to mitigate the problem in the interim, it is important that Europe and Africa must take this problem seriously. They must provide lasting solutions, that will help to keep Africans at home as useful vessels. In the recent past some have suggested the weird idea of creating a new nation, to be known as the 'Refugee State. Although such ideas were condemned for being weird, it only shows the kind of intellectual and robust debate going on the refugee crises in Europe. Therefore, countries like Nigeria that already have organisations such as the Border Community Development Agency, should fund the agency so that it can upgrade and modify its border communities. These should act as buffer zones where illegal migrants can be intercepted, before they make their journey through hell to Europe (which they consider to be an Eldorado).

\section{Promotion of Good Governance and Accountability}

African governments must begin to take the task of governance seriously by ensuring strict compliance to budget implementation, and ensuring the pursuit of transparency and accountability. If the needed infrastructures are provided in the continent, it will provide the platform for indigenous businesses to thrive. Once individuals can fend for themselves and provide themselves basic conditions for living, they will not be attracted to give themselves out as slaves. Therefore, the infrastructure deficit will need to be urgently addressed. In this regard, Europe could assist African nations to address their electricity gaps, and invest on roads infrastructural development, to promote internal trade and trade with Europe.

\section{Conclusion}

In this paper, we have examined the political economy of trans-border migration crises and human trafficking in Africa, with the aim of proffering solutions to the problem posed by these migrational trends into Europe. The consequences of such migration, driven by the need to pursue greener pastures, have been hazardous on the migrants. Records of casualties crossing the Sahara desert and the Mediterranean Sea, show that over 3500 migrants died in 2015 alone. In spite of the hazards and casualties, hundreds of thousands of Africans from Nigeria, Niger, Eritrea, and Somalia, keep making these hazardous and dangerous trips. We have made a proposal on how to mitigate and completely eradicate these challenges, through the promotion of good governance and accountability by African governments. Strengthening of internal agencies that handle migration issues will go a long way in mitigating or completely stopping these illegal migrations and therefore promote a more peaceful World. 


\section{Bibliography}

Annual Activity Report 2016 - Frontex - Europa EU.

Arango J. (2000), Explaining migration: a critical view, "International Social Science Journal," 52 (165), pp. 283-296.

Aiyar S., Bergljot B., Nicoletta B., Helge B., Enrica D., Allan D., Christian E., Huidan L., Linda K., Sebastian S., Antonio S., Petia T. (2016a), The refugee surge in Europe: Economic challenges, International Monetary Fund.

Bauer T., Zimmermann K. F. (1999), Assessment of possible migration pressure and its labor market impact following EU enlargement to Central and Eastern Europe, A study for the Department of Education and Employment, UK. IZA Research Report no. 3, July.

Borjas G. J. (2008), Labor Economics, Fourth Edition, McGraw-Hill International/Irwin.

Dadush U. (2014), The effect of low-skilled labour migration on the host economy, Global Knowledge Partnership on Migration and Development Working Paper, April.

Ehrhart H., Le Goff M., Rocher E., Singh J. R. (2014), Does migration foster exports? Evidence from Africa, World Bank Policy Research Working Paper no. 6739.

Ellyatt H. (2015), Four reasons why Europe's migrant crisis matters, CNBC, 14 September.

European Commission (2015a), A European agenda on migration, Communication (2015), 240 final, 13 May.

European Commission (2015b), Common European Asylum System.

European Commission (2015c), The 2015 ageing report.

European Commission (2016), European agenda on migration.

European Parliament (2015), Economic challenges and prospects of the refugee influx.

European Research Area (2013), African migrants at work: Labour market integration in Europe \& reintegration of returnees, MAFE Project Policy Briefing no. 4.

Gursch-Adam R., Benková L. (2016), The impact of demographic developments in Africa on Europe, "European View," 15, pp. 291-304.

Hicks J. R. (1932), The Theory of Wages, Macmillan, London.

Hirschman A. O. (1958), The Strategy of Economic Development, Yale, New Haven.

ILO (2005), A Global Alliance against Forced Labour, ILO, Geneva.

International Migration Institute \& University of Oxford (2011), Exploring the future of migration in Europe, IMI Policy Briefing no. 8, July.

International Organization for Migration (2016), 2030 agenda for sustainable development.

Lewis W. A. (1954), Economic development with unlimited supplies of labor, The Manchester School of Economic and Social Studies 22, pp. 139-191.

Lucia Kurekova (2011), Theories of migration: Conceptual review and empirical testing in the context of the EU East-West flows being a Paper prepared for Interdisciplinary conference on Migration. Economic Change, "Social Challenge," April 6-9, 2011, University College London.

Mahmoud T. O., Christoph T. (2010), The Economics of Human Trafficking and Labour Migration: Micro-Evidence from Eastern Europe, 3rd IZA/World Bank Conference on Employment and Development in Rabat and the Annual Conference of the European Society for Population Economics in Sevilla.

Massey Douglass S., Arango J., Hugo G., Kouaci A., Pellegrino A., Taylor J. E. (1993), Theories of international migration: a review and appraisal, "Population and Development Review," 19 (3), pp. 431-466.

Massey Douglass S., Arango J., Hugo G., Kouaouci A., Pellegrino A., Taylor J. E. (1998), Worlds in motion. Understanding international migration at the end of the millennium, Clarendon Press Oxford. 
Mydral G. (1957), Economic Theory and Underdeveloped Regions, Duckworth. University Press, London.

Todaro M. P. (1969), A model of labor migration and urban unemployment in less-developed countries, "American Economic Review," 59, pp. 138-148.

Todaro M. P., Smith S. (2006), Economic Development, Addison Wesley, Boston.

UNESCO (2006), Human Trafficking in Nigeria: Root Causes and Recommendations, POLICY PAPER SHS/CCT/2006/PI/H/2 Policy Paper Poverty Series n 14.2 (E) Paris 2006.

United Nations Convention against Transnational Organized Crime and the Protocols Thereto, 2010.

Yaro A. J. (2008), Migration in West Africa: Patterns, Issues and Challenges, Centre for Migration Studies University of Ghana, Legon.

\section{Uwarunkowania gospodarcze i polityczne transgranicznych kryzysów migracyjnych i handlu ludźmi w Afryce}

\section{Streszczenie}

W związku z nieszczelnością granic w państwach Afryki, przemyt ludzi i dóbr stał się napędzanym popytem, globalnym procederem obejmującym komercyjne usługi seksualne, niewolniczą pracę, terroryzm oraz przestępczość narkotykową. Większość państw Afryki, a w szczególności Nigeria postrzegana jest jako państwo umożliwiające tego typu proceder. Najważniejszymi powodami zaistniałej sytuacji są: niski poziom bezpieczeństwa wewnętrznego, niestabilność polityczna, recesja ekonomiczna oraz upadek instytucji państwowych. Spośród wielu czynników wspierających taki stan rzeczy niniejszy artykuł zwraca szczególną uwagę na relację pomiędzy kryzysem migracyjnym oraz handlem ludźmi w Nigerii oraz towarzyszącymi mu efektami nigeryjskiej polityki gospodarczej. Dane zastosowane w badaniu pochodzą ze źródeł wtórnych. Niniejszy artykuł opiera się na neoklasycznej teorii polityki ekonomicznej migracji. Przegląd literatury przedmiotu z zakresu koncepcji teoretycznej wskazuje, iż handel ludźmi oraz przestępstwa związane z nielegalną migracją są dokonywane nie tylko w związku z potencjalnym zyskiem, ale także dokonują się w wyniku upadku instytucji państwa. Niniejszy artykuł stanowi rekomendację do zwiększenia bezpieczeństwa granic, co doprowadziłoby do ograniczenia przestępczości transgranicznej takiej jak przemyt narkotyków i handel ludźmi. Autor wzywa także do przywództwa zorientowanego na potrzeby ludzi, które mogłoby przyczynić się do ograniczenia procederów wymienionych powyżej.

Słowa kluczowe: migracja, handel ludźmi, przemyt narkotyków, terroryzm, komercyjne usługi seksualne, neoklasyczna polityka ekonomiczna. 
